van Wagtendonk, W. J., van Tijn, B., Litman, R., Reisner, A. \& Young, M. L. (1956). J. gen. Microbiol. 15, 617-619

\title{
The Surface Antigens of Paramecium aurelia
}

\author{
By W. J. van WAGTENDONK, THE LATE BARBARA van TIJN, \\ ROSE LITMAN*, A. REISNER AND MARGARET L. YOUNG \\ Department of Zoology, Indiana University, Bloomington, Indiana, U.S.A.
}

SUMMARY: A surface antigen preparation obtained from Paramecium aurelia absorbs from a concentrated antiserum approximately $\mathbf{7 4} \%$ of the total antibody absorbed by the intact animal. An antiserum prepared against this preparation immobilized $\boldsymbol{P}$. aurelia of the same serotype.

Antisera against the various serotypes of Paramecium aurelia are prepared by injecting homogenates of mechanically disrupted organisms into a rabbit (Sonneborn, 1950). These antisera contain antibodies against antigens other than the immobilization antigen (van Wagtendonk \& van Tijn, 1953). In an effort to obtain partially purified preparations of the immobilization antigen, preparatory to the determination of its chemical constitution, a method was devised to obtain the antigen without disrupting the cell. This antigen prepartion which includes the trichocysts, but not the cilia, will be referred to as the 'surface antigen preparation'. The properties of this preparation are described in this communication.

\section{RESULTS}

Paramecium aurelia, var. 4, stock 51.7, serotype A was grown in a bacterized lettuce extract medium. Several litres of a $\mathbf{2 4} \mathrm{hr}$. old culture were first concentrated by filtration through a Berkefeld filter. The organisms were then concentrated and partially freed from bacteria by electromigration through a sterile salt solution (van Wagtendonk, Simonsen \& Zill, 1952). The volume of the concentrated organisms was carefully measured and the number of $P$. aurelia present determined by a count of samples of a suitable dilution. Molar $\mathrm{NaCl}$ solution was added to the suspension to reach a final concentration of $0.06 \mathrm{M}$. The mixture was gently shaken for $1 \mathrm{~min}$. and centrifuged for $2 \mathrm{~min}$. at $600 \mathrm{~g}$. The supernatant fluid, containing the trichocysts (microscopical examination showed the absence of cilia) was carefully decanted and saved. The sediment was resuspended in $0.06 \mathrm{M}-\mathrm{NaCl}$ solution and treated in the same way. The two supernatant suspensions were combined, centrifuged for $1 \mathrm{hr}$. at $2000 \mathrm{~g}$ in a refrigerated centrifuge, dialysed for $24 \mathrm{hr}$. against running distilled water and finally concentrated by lyophilization.

The number of organisms present after the first treatment and after the second treatment was determined by a count of the organisms present in a suitable dilution and the loss by lysis calculated. It can be seen from Table 1

* Present address: Department of Biochemistry, University of California, Berkeley, California, U.S.A. 
that no lysis took place during the first salt treatment and that the loss due to lysis during the second treatment varied from 2 to $9 \%$, with a mean of $5.5 \%$.

The lyophilized preparations were taken up in $10 \mathrm{ml}$. of a salt solution according to Ringer (diluted $1: 10, \mathrm{v} / \mathrm{v}$ ) and $1 \mathrm{ml}$. portions were incubated with $1 \mathrm{ml}$. of $51 \mathrm{~A}$ antiserum (diluted $1: 2, \mathrm{v} / \mathrm{v}$ with diluted salt solution according to Ringer) for $1 \mathrm{hr}$. at $32^{\circ}$ and left standing at $4^{\circ}$ for $24 \mathrm{hr}$. The precipitate was centrifuged, washed once with the diluted salt solution and nitrogen determined using the micro-Kjeldahl method and the digestion mixture of Brüel, Holter, Linderstrom-Lang \& Rozits (1947). The nitrogencontent of the surface-antigen preparation was also determined.

Table 1. Effect of salt treatment on the lysis of Paramecium aurelia

\begin{tabular}{|c|c|c|c|}
\hline $\begin{array}{l}\text { No. of organisms } \\
\text { before salt } \\
\text { treatment }\end{array}$ & $\begin{array}{l}\text { No. of organisms } \\
\text { after lst } \\
\text { treatment }\end{array}$ & $\begin{array}{l}\text { No. of organisms } \\
\text { after 2nd } \\
\text { treatment }\end{array}$ & $\begin{array}{c}\text { Percentage } \\
\text { lysis }\end{array}$ \\
\hline 12,800 & 12,800 & 12,300 & $3 \cdot 9$ \\
\hline 13,500 & 13,500 & 13,150 & $\mathbf{3} \cdot \mathbf{0}$ \\
\hline 39,700 & 39,700 & 36,100 & $\theta \cdot 1$ \\
\hline 37,000 & 37,000 & 34,400 & $7 \cdot 0$ \\
\hline 174,000 & 174,000 & 159,000 & $8 \cdot 6$ \\
\hline 106,000 & 106,000 & 97,000 & $6 \cdot 6$ \\
\hline 93,000 & 93,000 & 91,000 & $2 \cdot 2$ \\
\hline \multirow[t]{2}{*}{120,000} & 120,000 & 116,000 & $3 \cdot 3$ \\
\hline & & & an 5.5 \\
\hline
\end{tabular}

Incubation of the antigen preparation with antisera prepared against homogenates of serotypes $51 \mathrm{~B}$ and $51 \mathrm{D}$ did not result in the formation of a precipitate. Furthermore, the antigen preparation formed only one ring when incubated with $51 \mathrm{~A}$ antiserum according to Oudin (1948).

Untreated Paramecium aurelia, serotype A, were incubated with the same serum and the amount of antibody absorbed determined. It can be seen from Table 2 that the absorption of antibody by whole organisms from a concentrated antiserum is only slightly greater than the absorption by the surface antigen preparation.

Table 2. Absorption of antibody from an antiserum prepared against a homogenate of Paramecium aurelia, var. 4, serotype $51 \mathrm{~A}$ by various preparations obtained from $\mathbf{P}$. aurelia

\begin{tabular}{|c|c|c|c|c|c|}
\hline Preparation & $\begin{array}{l}\text { No. of } \\
P . \text { aurelia } \\
\times 10^{5}\end{array}$ & $\begin{array}{c}\text { Total } \mathrm{N} \text { in } \\
\text { preparation } \\
(\mu \mathrm{g} .)\end{array}$ & $\begin{array}{c}\text { N per } \\
\text { organism } \\
\left(\mu \mathrm{g} \cdot \times 10^{5}\right)\end{array}$ & $\begin{array}{c}\text { Total N } \\
\text { absorbed } \\
(\mu \mathrm{g} .)\end{array}$ & $\begin{array}{c}\text { per } \\
\text { organism } \\
\left(\mu \mathrm{g} \cdot \times 10^{5}\right)\end{array}$ \\
\hline \multirow[t]{5}{*}{ Live } & $17 \cdot 4$ & $350 \cdot 4$ & 201 & $34 \cdot 5$ & 20 \\
\hline & $12 \cdot 0$ & $266 \cdot 3$ & 222 & $55 \cdot 0$ & 46 \\
\hline & $13 \cdot 5$ & $315 \cdot 2$ & 233 & $34 \cdot 9$ & 26 \\
\hline & $12 \cdot 0$ & $\mathbf{2 9 8 \cdot 3}$ & 249 & $32 \cdot 8$ & 27 \\
\hline & & & & Mean & $29 \cdot 7$ \\
\hline \multirow[t]{5}{*}{ Surface antigen } & $15 \cdot 9$ & $9 \cdot 2$ & $5 \cdot 8$ & $24 \cdot 0$ & 15 \\
\hline & $9 \cdot 1$ & $8 \cdot 6$ & 9.5 & $44 \cdot 1$ & 48 \\
\hline & $11 \cdot 6$ & $8 \cdot 6$ & $7 \cdot 4$ & $34 \cdot 0$ & 29 \\
\hline & $12 \cdot 0$ & $5 \cdot 2$ & $4 \cdot 3$ & $28 \cdot 2$ & 24 \\
\hline & & & & Mean & ( $29 \cdot 0$ \\
\hline $\begin{array}{l}\text { Supernatant of } \\
\text { homogenate }\end{array}$ & $14 \cdot 0$ & $226 \cdot 8$ & 162 & $72 \cdot 1$ & 52 \\
\hline
\end{tabular}


Finally, surface-antigen preparations were injected into a rabbit and an antiserum prepared. This antiserum immobilized Paramecium aurelia, serotype $A$, in a dilution of $1: 200$ after $2 \mathrm{hr}$.

\section{DISCUSSION}

The experiments demonstrate that the surface antigen preparation from Paramecium aurelia, serotype 51 A, does absorb antibodies from a serum prepared against homogenates of the same type, and that an antiserum prepared against the surface antigen preparation does react specifically with organisms of the same serotype in causing immobilization of the organisms. The fact that the Oudin test shows only a single band indicates that the preparation may contain a single antigenic substance. It must be pointed out that the preparation contains trichocysts and any soluble surface substances associated with the organism. Whether the antigenic activity of the preparation should be ascribed to the trichocysts, to soluble substances, or to both, is not known.

A correction can be made in the value for the absorption of antibodies by the antigen preparation. If it be assumed that $10 \%$ of the originally present organisms lysed, these animals could have contributed to the absorption value of the preparation. In an earlier publication (van Wagtendonk \& van Tijn, 1953) the absorption by a supernatant fluid from a homogenate of Paramecium aurelia was determined. This value is given in Table 2 . The supernatant fluid of 14,000 lysed $P$. aurelia would contribute $7 \times 10^{-5} \mu \mathrm{g}$. of absorbed nitrogen to the determined value for the absorption by the surface antigen preparation. Thus the surface antigen prepared from one Paramecium would absorb $22 \cdot 0 \times 10^{-5} \mu \mathrm{g}$. or approximately $74 \%$ of the total antibody absorbed by the intact organism.

This work was carried out under the auspices of a grant from the National Cancer Institute of the National Institutes of Health (No. C-2160(c)-), a grant from the National Science Foundation, a contract between the Office of Naval Research and Indiana University (No. NR 135-274) and grants from the Rockefeller Foundation and Indiana University. One of us (A. R.) is a predoctoral fellow of the National Cancer Institute of the National Institutes of Health.

\section{REFERENCES}

Brüel, D., Holter, H., Linderstrom-Lang, D. \& Rozits, K. (1947). A micromethod for the determination of total nitrogen (accuracy 0.005 $\mu \mathrm{g} . \mathrm{N}$ ). Biochim. biophys. Acta, 1, 101.

Oudin, J. (1948). L'analyse immunochimique qualitative; Méthode par diffusion des antigènes au sein de l'immunsérum précipitant gélose. Ann. Inst. Pasteur, 75, 109.

Sonneborn, T. M. (1950). Methods in the general biology and genetics of Paramecium aurelia. J. exp. Zool. 113, 87.

Wagtendonk, W. J. van, Simonsen, D. H. \& Zirl, L. P. (1952). The use of electromigration techniques in washing and concentrating cultures of Paramecium aurelia. Physiol. Zoöl. 25, 312.

Wagtendonk, W. J. van \& TiJn, B. van (1953). Cross reaction of serotypes 51 A, $51 \mathrm{~B}$ and $51 \mathrm{D}$ of Paramecium aurelia, variety 4. Exp. Cell Res. 5, 1.

(Received 6 June 1956) 